\title{
SIR ARCHIBALD STEVENSON, HIS ANCESTRY, AND THE RIOT IN THE COLLEGE OF PHYSICIANS AT EDINBURGH
}

by

\section{W. B. HOWIE}

THE Royal College of Physicians in Edinburgh was founded in 1681. At the time of its foundation there were twenty-one founder fellows. Among the original fellows were Robert Sibbald, already a distinguished physician and man of science; Thomas Burnet of Crimond, Physician to the King in Scotland and author of the popular Thesaurus Medicinae Practicae; ${ }^{1}$ Andrew Balfour who, with Sibbald, had founded the Physic Garden in Holyrood Abbey and was himself a botanist of distinction;2 James Halket, four years later to become one of the first professors of medicine in the University of Edinburgh $;^{3}$ and Archibald Pitcairn, not only a future professor of medicine in Edinburgh, but in Leyden also. It might have been expected that the first President of the College would have been chosen from among this distinguished group, but when the fellows of the College met for the first time the physician elected to fill the office of President was none of these, but Dr. Archibald Stevenson. The choice of Dr. Stevenson as President would appear to have been quite a determined one, and no empty honour, for he was re-elected President in subsequent years, and remained in office until the election of 4 December 1684 when he was succeeded by Sir Robert Sibbald. ${ }^{4}$

To succeeding generations Stevenson is rather a shadowy figure. Unlike Sibbald, Pitcairn, or Burnet, he left no published works behind him upon which his theoretical beliefs can be judged, and nothing is known of his practical skills. In January 1684 however he delivered the first of the monthly discourses to be given before the College on the Polypus Cardis 'to the great satisfactione of the Colledge,' ${ }^{5}$ and some nine years later gave another upon Diabetes. ${ }^{6}$ To give 'great satisfactione' to an assembly of critical colleagues suggests that his views were at least sound and orthodox, and such evidence as exists of material prosperity suggests that patients viewed his therapeutic skills with favour. In the Edinburgh Stent Roll of 1699 the value of his property is given as being $£ 160$ scots, twice the amount paid by Pitcairn, and exceeding that of the other established physicians such as Olyphant, Smelholme, Eccles, and Trotter, though much less than the sum paid by Sibbald who was rated at $£ 350$ scots. ${ }^{7}$ Generally he must have been considered one of the Edinburgh physicians of reputation. In July 1681, when the Court of Session was required to adjudicate in a cause between the apothecaries and the surgeon apothecaries of Edinburgh, the Judges resolved to seek the advice of four Edinburgh physicians before reaching a decision,

\footnotetext{
${ }^{1}$ Thesaurus Medicinae Practicae was first printed in London in 1673. Before its final edition in Geneva in 1698 it ran through twelve editions. (Anderson 1 p. 494.)

Comrie, pp. 183-84.

- Three Professors of Medicine held office simultaneously, Sir Robert Sibbald, Halket, and Pitcairn. They were appointed in 1685 (Comrie, p. 185.)

Ritchie, p. 241.

- Ritchie, p. ix.
} 


\section{W. B. Howie}

and included Stevenson among the four selected, the others being Sir David Hay, Balfour, and Burnet. ${ }^{8}$

In addition to professional reputation, another factor-seniority-could have played a part in securing Stevenson's election as President, but the position here is confused and his actual degree of seniority indefinite. In 1681 Stevenson was 52 years of age, and, having taken the M.D. of Leyden in 1661, had been qualified for twenty years. ${ }^{9}$ Balfour, his close contemporary, was only a year younger and had also qualified M.D. in 1661 , but at Caen. ${ }^{10}$ Burnet was younger in years, being 43 , but he had graduated at an unusually early age at Montpellier in 1659 , so that in length of practice since qualification he exceeded the two older men by two years. Sibbald was younger, still being only 40 , but he was nineteen years qualified, having graduated M.D. at Angers in 1662 . He had been a student at Leyden in 1660 and would actually have been a contemporary of Stevenson during his student days there. ${ }^{11}$ From the point of view of seniority Pitcairn was out of the race being amongst the youngest of the fellows, 28 years of age, and an M.D. of Rheims of only one year's standing. ${ }^{12}$ Halket was 26.13

\section{THE EARLY LIFE OF SIR ARCHIBALD STEVENSON}

Archibald Stevenson was born in 1629, the youngest of a family of seven in which there were four sons and three daughters. His father was the Rev. Andrew Stevenson, at that time Professor of Philosophy in the University of Edinburgh, and his mother Agnes Cathkin. In 1634 his mother died. Shortly afterwards Andrew Stevenson married a second time, his second wife being Bethia Cathkin ${ }^{14}$ cousin of his first wife. Bethia was a widow, having been the third wife of Cuthbert Miller W.S., whom she had married in February $1628^{15}$ and who had died on 31 October $1631 .^{16}$ From about the age of nine Archibald was brought up in Dunbar. There was a grammar school in Dunbar-in 1594 the Presbytery of Jedburgh was commissioned to examine a schoolmaster and decide upon his suitability to teach in the grammar school ${ }^{17}$ and Archibald may have received his early education there. He matriculated as a student in Leyden in 1659, and secured the M.D. of that University in $1661 .^{18} \mathrm{He}$ returned to Edinburgh and engaged in practice in the city. On 14 August 1662 he married Elizabeth Ramsay, the daughter of John Ramsay of Idingtoun by his wife Egidia Kellie. Of this marriage there were four sons and four daughters-George, William, Andrew, Archibald, Elizabeth, Margaret, Jean and Agnes. George became a surgeon, married and had descendants ultimately to be found in the United States. William, Archibald, Andrew, Margaret and Jean all died unmarried, while Agnes the fourth daughter married Colin Arthur a surgeon apothecary in Fife. ${ }^{19}$ In 1693

- According to Sibbald the question posed by the Lords of Session concerned the title of surgeon apothecary "whither ther were any such conjunction of ys employments in other countryes, and whither or not it was expedient for the Leidges, they should be joined in one person here.' Upon this the four referees consulted the remainder of the physicians in Edinburgh, and resolved to report 'yt yr was no such conjunction of these arts elsewhere, and yt it was very prejudiciall both to the leidges and to the Physitians.' (Memoirs, p. 78.)

- Guthrie, p. 115.

12 Pitcairn, p. 370.

18 Paton, p. 470.

10 Ritchie, p. 204.

is Guthrie, p. 115.

16 History of the Society of Writers to His Majesty's Signet, p. 145.

17 Grant, p. 86.

10 Guthrie, p. 115.

11 Guthrie, p. 115.

14 Scott: Fasti.

10 Ritchie, p. 201. 


\section{Sir Archibald Stevenson}

Elizabeth, the eldest daughter, married as his second wife Archibald Pitcairn. Pitcairn had just completed his first session as Professor of Medicine at Leyden at the time of this marriage, and is generally said to have been prevented from returning to Leyden by the parents of his bride who refused to allow her to leave the country. ${ }^{20}$ Elizabeth Pitcairn outlived her husband by forty-one years, dying in a very advanced age' on 19 October $1754 . .^{21}$

In 1682 Stevenson was knighted. He received this honour in company with two of his rivals. On a Saturday night in 1682 Sibbald was directed by one of the Household to wait next day upon the Duke of York at Holyrood after the forenoon sermon and to bring with him Dr. Stevenson and Dr. Balfour. Sibbald and Stevenson thought that they had been sent for 'to receive his R.H. commands anent the Colledge, for that he was to goe away shortly. Bot to our surprisall, ther was ane carpet layed, and we wer ordered to kneel, and were each of us knighted by his Royal Highness yn Commissioner. ${ }^{22}$

\section{SIR ARCHIBALD, THE COLLEGE, AND THE RIOT}

Sir Archibald's knighthood was a justifiable recognition not only of his position in the profession, but of his work in the College. He had borne part of the expense of its foundation, ${ }^{23}$ had been constant in his attendance on business, and had taken part in all its activities. From the foundation of the College until the end of 1684 when he ceased to be President, forty-one meetings of the College, and three of the Council are minuted. Of these Stevenson attended forty-one, Sibbald (who was Secretary during this period) attended the same number, Balfour thirty-nine, and Pitcairn thirty-six. Significantly Burnet attended just over half the meetings, being present on only twenty-two occasions. ${ }^{24}$ Even after he had ceased to be President of the College Stevenson remained regular in attendance. He was again elected President in 1693 and in 1694, but by this time relationships in the College were becoming strained. Two parties were appearing, the one led by Sibbald and Burnet, the other by Stevenson and Pitcairn. Sibbald's, which was the slightly larger group, contained the older members and all the surviving founder fellows, while the Stevenson-Pitcairn group consisted of younger men who had entered the College in the years after its foundation.

One of the first difficulties between Stevenson and Sibbald arose over the preparation of a pharmacopoeia, a subject dear to Sibbald's heart. In 1683 after a good deal of preliminary work the pharmacopoeia was said to be ready for publication and Sibbald reported on arrangements he had made for its printing, but no pharmacopoeia appeared. In 1694 when Stevenson was again President the pharmacopoeia had still not been published, and the matter was raised anew. It was resolved that the President should appoint a fellow to prepare a draft for consideration. In 1696, after the troubles to be recorded later, the College had to send two members to Sir Archibald

20 Scots Magazine, 46, p. 172.

22 Sibbald's Memoirs, pp. 81-82.

21 Scots Magazine, 16, p. 500.

22 Sibbald comments in his Memoirs that it cost a great deal of money to defray the charges of establishing the College. 'Wee payed considerably each of us ... Dr. Steenson, and Dr. Balfour and I, were at double expense, in regard that we sollicite the matter, and met with the Lawers and Clerks, and frequently treated ym.' (Memoirs, p. 80.)

2 Ritchie, p. 69. 


\section{W. B. Howie}

Stevenson to demand that the copy of the pharmacopoeia compiled by the College, and other College papers in his hands, be delivered up. After further consideration by various committees the work was completed, and the pharmacopoeia finally appeared in 1699, eighteen years after it had first been proposed. ${ }^{25}$ Sibbald in his memoirs attributed the delay to 'malice' and obstruction by 'faction'26 and by this undoubtedly meant the Stevenson-Pitcairn group. ${ }^{27}$

Worse however was to come. One of the earliest resolutions of the College had been to establish an examination governing entry to the College, an action necessary to ensure a reasonable standard among fellows. Graduates of Scottish universities were admitted by virtue of their degree and without examination (the price of acquiescence by the universities to the foundation of the College ${ }^{28}$ but all others had to satisfy the College as to their suitability for entry. Initially the examination was divided into three parts, and conducted by examiners appointed specifically for each candidate as he applied for admission. This system must have had the obvious disadvantage of inequality of assessment, but was retained until December 1693, when it was proposed and agreed that for the future five examiners should be appointed annually to conduct all the examinations throughout the year. For an examination to be legal at least three of the examiners had to be present, together with the President or his deputy, and as many of the fellows as, with the examiners, should make up a quorum. At a second meeting seven days later this new arrangement was confirmed, and the five examiners appointed were Sibbald, Trotter, Pitcairn, Eccles and Olyphant; two of the Sibbald group and three of the Stevenson party. ${ }^{29}$ The following December these five were continued in office, but on 17 January 1695 the appointments were reconsidered. Pitcairn, Eccles and Olyphant were continued, but in place of Trotter, now President, Sir Archibald Stevenson was appointed, and in place of Sir Robert Sibbald, who had decided to withdraw, Dr. Halket. These five were to remain in office till the following December. ${ }^{30}$ The interesting feature is that four of the five examiners were now of the Stevenson party, and that for some reason Sibbald had become opposed to the system. Meetings of the College continued till July, enlivened perhaps, after the business was over, by discussions concerning Pitcairn's Disputatio de curatione Febrium published that year, and the anonymous attack upon Pitcairn and his methods Apollo Mathematicus, or the Art of curing diseases by the Mathematicks, known to have been written by Edward Eizat. A meeting was to have been

\footnotetext{
${ }^{25}$ Ritchie, pp. 72-76.

26 'In the tyme I was president ... The Pharmacopaea Edinburgensis was composed, and licensed to be printed by the Chancellor, and the Printer agreed to print it gratis, and give the College a competent number of copies, and take his hazard of vending the rest; bot by the malice of some, it was laid aside for ten years thereafter.' (Sibbald's Memoirs, pp. 85, 96.)

${ }^{27}$ It is interesting to note that the Royal College of Physicians of London also experienced difficulty in producing its first pharmacopoeia. The compiling of a pharmacopoeia was first considered at the June comitia of 1585, but the Pharmacopoeia Londinensis did not appear till 1618, thirty-three years after it had first been suggested. The real difficulty was that the production of such a volume was a very considerable undertaking for a group of men fully occupied by their own affairs. (Clark, 1, pp. 158, 227-28.)

${ }_{28}$ The universities at first opposed the proposal for establishing a College of Physicians, and were supported by the Bishops and Archbishops who had close connections with the universities. Negotiations however won the universities over and they changed sides. "We soon did agree with the universities and Bishops, and yr were some conditiones insert in the patent in yr favours, and they became strong solicitours for us.' (Sibbald's Memoirs, p. 79.)

s? Ritchie, p. $x-x i$.

so Ritchie, p. 106.
} 


\section{Sir Archibald Stevenson}

held in August, but for some reason this meeting was not held, and then on 14 September dramatic events began. Edward Eizat had applied for a licence to practise medicine without examination on the grounds that he had received his degree before the establishment of the College, and his application was to be considered on that day. In an attempt to prevent the meeting taking place Stevenson, who held the keys of the College, ${ }^{31}$ refused to give them up, and the fellows, denied their usual place of meeting, were forced to gather in the lodgings of the President, Dr. Trotter. By a majority vote Eizat was received as a candidate, and immediately also as a fellow. With Eizat's vote added to the strength of the Sibbald group, a request from Dr. Gilbert Rule for admission to examination was accepted, and it was further agreed by a majority vote that the method of examination should be the original one, and that the new system of having examiners appointed annually should be abandoned. At this meeting, excluding the President, there were six of the Sibbald party and four of the Stevenson group, the Sibbald party being increased to seven with the election of Eizat. Another supporter of Sibbald, Dr. Mitchell, was also admitted as a fellow, further swaying the balance in favour of the Sibbald group, the number of effective fellows having been fairly evenly divided up to this time. Two days later Dr. Blackader was admitted candidate and fellow, and on 2 October, Dr. Rule's examination being completed, he was upon the same day also admitted fellow. On 4 November Dr. Dundas, having completed his examination that day, was admitted a fellow, so that the Sibbald party with five new recruits in the course of seven weeks, was now well in the ascendant. By 7 November the Sibbald party felt strong enough to strike down the opposition. Dr. George Hepburn, a friend of Pitcairn, had replied to Eizat's attack on Pitcairn in a pamphlet Tarugo Unmasked. Hepburn's pamphlet, in the manner of the times, was forceful in character and not over-particular in the nature of its attack. At the meeting on the 7th it was reported to the College that a pamplet had been written by a fellow of the College without licence from the College and a committee was set up to examine it. On the 14th the pamphlet-Tarugo Unmasked-was reported upon, and by a majority vote found to be censurable. Hepburn was summoned to appear before the College on 22 November. At the next meeting on 18 November Stevenson and Pitcairn attended for the first time since before the lock-out of 14 September, and Pitcairn on behalf of himself and others of his party, presented a paper attacking the conduct of Trotter, the President, and several other members of the College. The attack was referred to a committee for consideration, the committee consisting of the President himself, Sibbald, and four other members of the Sibbald party. The conclusion of the Committee-that it was 'a calumnious, scandalous, false and arrogant paper'-is not, therefore, surprising, and on the report being presented at the next meeting on the 22nd Pitcairn was suspended. On 3 December Dr. Hepburn was suspended for his authorship of Tarugo, and the attack switched to Dr. Olyphant the Treasurer, who was ordered to give in his accounts immediately. Next day he was suspended for not appearing at the special meeting called that day to receive the accounts, and on the 5th the annual elections were held.

$\because 1$ There is some confusion as to the exact site of the College meeting place but it has been suggested that it was in part of Stevenson's house. If this was so it would be similar to the arrangement in the early days of the Royal College of Physicians of London whose meeting place was in Linacre's house, The Stone House in Knightrider Street (Clark, 1, p. 52.) 


\section{W. B. Howie}

Pitcairn, Stevenson and their friends appeared, but one of the city Baillies being present supported by a number of the Town Officers, they were forcibly removed from the meeting. The ejected group held a meeting at Stevenson's house and elected Sir Archibald President of the College, but it was an empty gesture. The whole of the remaining members of the Stevenson party-Eccles, Robertson, Smelholme, Melville and Sir Archibald himself were suspended from their fellowships, and the Sibbald party, though harried by law suits, remained victors in the field. This was the 'riot in the College'. ${ }^{32}$

\section{BACKGROUND AND MOTIVATION OF THE RIOT}

The bitter antagonisms displayed by men in disputes of this kind are never easy to understand. Considered superficially there was the disagreement over the method of examination, but this may have been more a product of the dispute rather than the cause. Again there was Eizat's attack upon Pitcairn, and Hepburn's onslaught upon Eizat, but this sort of thing was not uncommon and could well have been confined to a paper war outside the College walls. There must have been something more, a deep personal animosity between the key figures in the dispute, between Stevenson and Sibbald, between Stevenson and Burnet, between Sibbald, Trotter and Pitcairn. But to reach such a conclusion intensifies rather than simplifies the problem. To identify the causes of personal incompatibility amongst contemporaries is difficult enough; to attempt to do so after some two hundred and seventy years adds to the difficulties incalculably. But in this instance a reasonable guess can be hazarded. Between the principal participants in the quarrel vital differences can be demonstrated in two of the mainsprings in the social life of the period-politics and religion. In seventeenth-century Scotland there was no subject more likely than these to rouse deep feeling, deep hatred, and a greater determination to stand for the right. There was also perhaps a problem of social status in a socially conscious world. To demonstrate these factors in the relationships between the various opponents, particularly between Sibbald and Stevenson, certain features of the life and ancestry of each must be considered.

\section{SIR ROBERT SIBBALD'S ORIGIN AND RELIGION}

Sir Robert Sibbald was born on 15 April 1641 the youngest son of David Sibbald, keeper of the Great Seal under the first Earl of Kinnoul, Lord High Chancellor of Scotland from 1622 till 1634. His mother was Margaret Boyd, eldest daughter of Robert Boyd of Kipps in Linlithgow, an advocate. ${ }^{33}$ His grandfather was a Fife laird, Andrew Sibbald of Rankeillour; his grandmother was Margaret Learmonth, daughter of another Fife laird, George Learmonth of Balcomie, whose wife Euphemia Leslie was a daughter of the Earl of Rothes. ${ }^{\text {3 }}$ His uncle, George Sibbald, a physician of distinction, succeeded to the estate of Gibliston near Arncroach in Fife to which he was heir. ${ }^{35}$ Sibbald's descent therefore was from the smaller landed gentry, and had indeed amongst it a mingling of the aristocratic. He was, as appears from his memoirs, very conscious of his social status. He disapproved of the marriage of his sister Geels to James Chalmers, an advocate, not only because of his age-he was

ss Ritchie, pp. 173-78.

s4 Wood, p. 440.
Sibbald's Memoirs, pp. 49-50.

25 Wood, p. 268. 


\section{Sir Archibald Stevenson}

thirty years older than she was-but also because he 'was not of yt birth or education was fitt for her' ${ }^{36}$ Of even greater significance from the point of view of his relationship with Sir Archibald Stevenson was his continuing disapproval of his brother-in-law when, after Geels Sibbald's death, he married, as his second wife, Katharine Adam, the daughter of Colin Adam the minister of Anstruther. This marriage, in Sibbald's view was to a woman 'of a much inferior degree' to his sister Geels."

The Sibbalds, at the time of Sir Robert's birth and during his early childhood, were prosperous. After the death of the Earl of Kinnoul David Sibbald, according to his son, was able to 'live privately upon his own Fortune', ${ }^{88}$ but when Robert was nine years old disaster befell. The family were in Dundee when it was sacked by the Cromwellian army under the command of Monck in 1650. The uncontrolled looting of the English troops after the capture of the town proved disastrous to its economy for years to come. ${ }^{30}$ The Sibbald family suffered the same fate as the other inhabitants; David Sibbald was wounded in the fighting, and the family robbed of everything it possessed. ${ }^{40}$ As a result of this loss David Sibbald fell into debt. 'My father' wrote Robert in his memoirs 'contracted no debt till after the loss he sustained at Dundee, which grew considerable; blessed be God, all his, and my mother's debts were payed by me.'41

Young Robert Sibbald was educated first at Cupar in Fife, then at the High School in Edinburgh, and finally at the University there. His mother had hoped that he would enter the church, but Sibbald had developed 'a disgust' for Presbyterianism ${ }^{42}$ and at university had fallen under the influence of Robert Leighton, Principal of the university, and later (though unwillingly) Bishop of Dunblane and Archbishop of Glasgow. ${ }^{3}$ Leighton, a moderate and pious man, probably led him to the Episcopalianism which he ultimately adopted." Instead of the church, Sibbald entered upon the study of medicine, and after a period at Leyden and Paris took his M.D. at Angers. ${ }^{45}$ He returned first to London and then to Edinburgh where, after just under two-and-a-half years' study of the subject, he entered upon the practice of medicine. His father had died while he was abroad, and after the death of his mother he married in April 1677 Anna Lowes, sister of James Lowes of Merchistoun. At the time of his marriage he was 36 years of age, and his bride 'twenty two or so'.46 Their married life was short, she died of a fever in December 1678, and he married a second time in November 1682 Anna Orrock, daughter of a Fifeshire laird."77

"2 Sibbald's Memoirs, p. $67 . \quad 37$ Sibbald's Memoirs, p. $68 . \quad 28$ Sibbald's Memoirs, p. 49.
"S Smout, p. 140. 'The subborness of the people, according to Monck, enforced the soldiers to plunder the town.' (Rait, p. 237.)

10 'We were all plundered, and lost in jewells, silver work, and money, and all the furniture of the house, to a great value.' (Sibbald's Memoirs, p. 52.)

11 Sibbald's Memoirs, p. 61.

4s 'My mother would have had me studie divinity, but yr were great divisions amongst the presbyterians then some for the publick assemblies of the church, some against ym, and they wrott reproachfull discourses against others, and occasioned factions in the state and private families, which gave me ane disgust of them.' (Sibbald's Memoirs, p. 55.)

' 2 Robert Leighton's father Alexander, a Puritan clergyman in England (though a St. Andrews graduate), had fallen foul of the authorities by publishing anti-episcopal works. Unable to hold an incumbency in the Church he attempted to support himself by the practice of medicine in London, and was one of the clerics hounded by the Royal College of Physicians for practising without licence. (Clarke, 1, p. 247.)

${ }^{5}$ He stayed a year-and-a-half at Leyden, nine months in Paris, and a month in Angers. (Sibbald's Memoirs, pp. 56-9.) ${ }^{6}$ Sibbald's Memoirs, p. 71.

"Sibbald's Memoirs, p. 81. 


\section{W. B. Howie}

Some years before this Sibbald had come under the influence of James Drummond, Fourth Earl of Perth. Perth had played a leading part in the opposition to Lauderdale, and on the fall of Lauderdale in May 1682 became Lord Justice General. ${ }^{48}$ Through his influence Sibbald in September 1682 was appointed Geographer Royal for Scotland, and Physician to Charles II.49 In June 1684 Perth became Lord Chancellor of Scotland and principal manager of Scottish affairs. Upon the death of Charles II and the succession of James VII, Perth was continued in office, and hitherto an Episcopalian ${ }^{50}$ now declared himself converted to Roman Catholicism. ${ }^{51}$ Sibbald out of 'affection' for the Earl resolved to embrace that religion also. This was made the easier in that a dispute he had had with the Bishop of St. Asaph upon the antiquities of Scotland and its Kings had occasioned in him 'some contempt of the English Clergy', and some 'prevarications of some of our own folks upon some heads, had loused the attachment I had for our owne Religion'.52 His final conversion was brought about by Perth reading to him a paper the Duchess of York (James VII's Queen) had written upon her conversion. 'I knew not how it came about, I felt a great warmness of my affections while he was reading and discoursing, and yrupon as I thought, oestro quodam pietatis motus, I said, I would embrace that religion, upon which he took me in his arms and thanked God for it'. ${ }^{53}$ With the growing unpopularity of James and his Catholic supporters Sibbald's house in Carrubers Close was attacked by a mob, and having narrowly escaped with his life he was forced to flee to London where he remained for some months. ${ }^{54}$ Exiled from home he now began to repent his rashness in acquiescing so readily to his patron's persuasion. He became alarmed at the influence the Jesuits exerted on the $\mathrm{King}$, and perceived that the people were becoming restless, and that 'they would overturne the Government'. He found besides the keeping of Lent 'when few good fishes could be had', injurious to his health, and became increasingly ill. ${ }^{55} \mathrm{He}$ became convinced he must go back to Scotland 'and return to the church I was born in'. He returned to Edinburgh, abandoned Catholicism and was received back into the Scottish Church by the Bishop of Edinburgh. He retired into the country and for a time remained at Kipps. His conscience was soothed by events. 'After my returne, it pleased God the popish interest decayed dayly, and good men thought I by my returne had done it more damage than my joining had profited ym.'56

\section{SIR ARCHIBALD STEVENSON'S ANCESTRY.}

The ancestry of Sir Archibald Stevenson was much more humble than that of Sir Robert Sibbald. Sir Archibald's father, the Rev. Andrew Stevenson, was the eldest

\footnotetext{
${ }^{48}$ Anderson, 3, p. 284.
}

so Upon Sibbald's first contact with the Earl he 'was very observant of the rites of the Church of England, and had the English service allways in his family'. (Sibbald's Memoirs, p. 73.) He had also 'many tymes signified the aversion he had for some of the doctrines of the Church of Rome.' (Sibbald's Memoirs, p. 86.)

b1 Anderson, 3, p. $284 . \quad$ "s2 Sibbald's Memoirs, p. $86 . \quad$ Sa Sibbald's Memoirs, p. 88.

s4 During his stay in London he became an honorary Fellow of the Royal College of Physicians of London. (Sibbald's Memoirs, pp. 91-2, and Clark, p. 337.)

ss Sibbald's Memoirs, p. 93.

so Sibbald's Memoirs, p. 94. Gradually he returned to practice, to the affairs of the College, and to his scholarly pursuits. He died in Edinburgh on 9 August 1722 at the age of 82 years, and was buried in Greyfriars Kirkyard. (Ritchie, p. 262.) 


\section{Sir Archibald Stevenson}

son of another Andrew, a merchant in Edinburgh, ${ }^{57}$ and his mother Agnes Cathkin was the daughter of an Edinburgh bookseller. The Rev. Andrew was born in a momentous year-on 29 October 1588. He graduated master of arts at Edinburgh in 1609 at the age of 21 , and initially appeared intent upon an academic career. In 1611 , although only 23 years of age, he was appointed after competitive trial Professor of Philosophy at the university, but the appointment was rather a curious one, in that it was conditional upon the existing professor being unable to resume his duties. Andrew Young, the holder of the Chair, had been suffering for some time from an obscure and chronic disease which appeared likely to terminate in his death, but it was stipulated that if he should recover Stevenson should withdraw and Young regain his Chair. Unfortunately for the Rev. Andrew the physicians, or a strong natural constitution, finally won the day, and Young was restored to health. In accordance with the agreement the Rev. Andrew gave up the appointment, and Young returned to his Professorship which he continued to hold for a further twelve years. Upon Young's death in 1623 the Rev. Andrew finally succeeded to the Chair, having, in the meantime, acted as Professor of Humanity in the university. ${ }^{58}$

It is however in the Rev. Andrew's religious attitudes and beliefs that the main interest lies. He appears to have been one of the members of the extreme Presbyterian party. In 1618 he was one of those who took a stand against the Articles of Perth, ${ }^{50}$ an attitude which he held in common with his father-in-law James Cathkin, and in 1635 he gave further proof of his Presbyterianism. In that year Charles I came to Scotland for his coronation. ${ }^{60}$ Intent upon the task of continuing the Anglicanization of the Scottish Church begun by his father James VI, he brought with him on his journey north his advisor on ecclesiastical matters in England, William Laud. Upon his arrival in Edinburgh, as an intended honour for the capital, Charles split off that part of the diocese of St. Andrews lying south of the Forth and erected it into a new See of Edinburgh, making Edinburgh an Episcopal city, and St. Giles a cathedral. ${ }^{61}$ In this climate of royal opinion it is not surprising that many bowed before the storm, and the incumbents in office in King James's College were no exceptions. 'The Prelats and Ministers of their way, after many years labour, at length this year prevailed so far with the Maisters of the Colledge (only Mr. Andrew Stevenson protesting to the contrary), that the Short Confession of Faith, called the Covenant (which purposely had been drawn up and sworn in the year 1581, to close the doors against the re-entry, as well of Episcopacie as Popisme, and all the branches of both), should be laid aside, and instead thereof the candidates, yearly should subscribe ane short oath against Papistrie.' ${ }^{\text {'2 }}$ In times such as these opposition of this type did not lack danger, and for the Rev. Andrew to 'protest to the contrary' was no light or safe action. At this time Archibald Stevenson was six years of age.

${ }^{57}$ On 10 November 1624 Andrew Stevenson 'one of the regents of King James his college' was admitted Burgess and Guild Brother of Edinburgh as 'eldest son to umq. Andro Stevenson' who had also been a Burgess. (Watson, p. 469.)

${ }_{58}$ Ritchie pp. 196-7, quoting The History of the University of Edinburgh from 1580 to 1646, by Thomas Crawford A.M., Professor of Philosophy and Mathematics in the College of Edinburgh, 1646, pp. 73, 96.

60 Scott: Fasti.

- Charles had been King for ten years, but until 1635 had been crowned only in England and not in his Scottish Kingdom.

1 Burleigh, p. 211.

c2 Ritchie, pp. 197-8, quoting Crawford p. 126. 


\section{W. B. Howie}

Andrew Stevenson's opposition to the Articles of Perth resulted in his being recommended by the revolutionary General Assembly of 1638 as one of those suitable for the supply of vacancies. ${ }^{63}$ This Assembly, wholly under the control of the Covenanting party, with Alexander Henderson, Minister of the Parish of Leuchars in Fife as Moderator, and Archibald Johnston of Wariston as Clerk (the two members of the Church commissioned to draft the National Covenant) continued its deliberations in spite of its dissolution by Charles' Commissioner who pronounced its continuance treasonable. It declared the Five Articles contrary to the Confession of Faith, swept the office of Bishop out of the Kirk, and condemned the Prayer Book and the Court of High Commission as inimical to the beliefs of the Scottish Church and introduced without authority. ${ }^{64}$ With the Presbyterian party so powerfully in the ascendant Andrew Stevenson could now safely pass to the ministry, and on 19 December 1639 he was admitted minister of the Parish of Dunbar. Here he remained until his death on 13 December 1664, except for a period in 1650, when, during the invasion of the Cromwellian army (the Covenanting interest being now in support of Charles II) he was forced to withdraw from Dunbar, where the Scottish Army had been defeated in battle on 3 September, to seek shelter, as the Sibbald family had done, in Dundee. ${ }^{65}$

The Rev. Andrew, as has been mentioned, was twice married, first to Agnes Cathkin, the daughter of James Cathkin, and secondly to Bethia Cathkin, daughter of James's elder brother Edward. Bethia also predeceased her husband, dying on 26 March 1640.66

James Cathkin, the father of Agnes Cathkin, was born about 1559.87 In his early days he is said to have been a worker in mariken leather, ${ }^{68}$ and at the time of his marriage to Janet Mayne on 22 February 1597 he is listed in the register of marriages as 'James Cathkin, skinner'."9 At what stage James Cathkin took up bookselling is uncertain but it is probable that it was upon the death of his brother Edward in $1601,{ }^{70}$ a supposition supported by the fact that he is described in Edward's Will as 'James Cathkin, skynner, burgess of Edinburgh'. ${ }^{11}$

James Cathkin appears to have adventured from time to time into the production side as booksellers of the period did, and to have been in partnership with Andro Hart in some printing business. Andro Hart, one of the most important Scottish booksellers and printers of the first half of the seventeenth century, was of the same religious party as the Cathkins, and was suspected from time to time by King James of printing seditious volumes. Despite this religious, business and even personal association (for Andro was probably the brother-in-law of Edward Cathkin) there appears by 1614 to have been a disagreement between Hart and Cathkin, for on 14 July that year James, with other booksellers in Edinburgh, appeared before the Privy Council to protest against Andro Hart's claim to have the monopoly of im-

Scott: Fasti.

Scott: Fasti.

-O Paton, p. 121.

In therhaps there is also a clue in Edward's Will as to why James Cathkin became a bookseller. In the list of his debts Edward notes first 'Item thair wes awin be the said umquhile Edward Cathkin to his broder, James Cathkin, skynner, burgess of Einburgh, the sume of Imli of borrowit money; and ordanis him to be payit of the first and reddiest of his guidis.' This amount is, of course, in pounds scots, but is still a fair sum. Almost all the capital available to pay off the debts owed was in stock and business property, and James may have accepted stock in payment of his loan. (Bannatyne, 2, p. 231.) 


\section{Sir Archibald Stevenson}

porting books from England and abroad. The Council supported them and gave a decision in their favour. ${ }^{72}$

This was the most peaceful appearance James Cathkin made before the Council or any similar authoritative body. The remainder-and there were many-were more stormy. His first recorded conflict with authority was in 1584. This was the year of the 'Black Acts', when the Scottish Parliament under the sway of Arran passed a series of laws declaring among other things the supremacy of the King in both spiritual and temporal matters. The Act concerning the supremacy of the King required all Ministers, Readers, and Masters of Colleges, to appear within a period of forty days to subscribe the Act and submit themselves to the Bishops. ${ }^{73}$ Among those proving unruly on this occasion was John Craig, one of the ministers of Edinburgh. He was summoned before King James at Falkland, and after examination, ordered to cease preaching. Upon the following Sunday the Archbishop of St. Andrews took his place, and a tumult broke out among those members of the congregation who supported the Presbyterian interest. Among the leaders in the tumult were James and Edward Cathkin. They were summoned to appear before the Council 'for knocking upon the church door while the Bishop was at prayer', but fled to England before they were arrested. Both were banished from the kingdom for their sedition. ${ }^{74}$

Within a year Arran had fallen from power, policy changed, and the Cathkins were able to return to Edinburgh and live peaceably for another twelve years. In 1596 however they were again in difficulties. The Presbyterian party temporarily in the ascendant had begun to criticize what they held to be lukewarm support from the King, and James, with just cause, growing weary of subjects who thundered sermons of denunciation weekly from their pulpits, determined to bring the issue to trial. He summoned David Black, minister of St. Andrews, and protégé of Andrew Melville $^{75}$ the leader of the church party, to appear before the Privy Council on a charge of preaching sedition. Black rejected the authority of the Council over church utterances, and was supported in his defiance by the ministers of Edinburgh. Despite this the trial continued, and as tension rose a riot broke out in the capital. The riot was supressed, the ringleaders arrested, and Edinburgh threatened with loss of its status as capital of the kingdom. ${ }^{76}$ Among those ordered to be arrested for their part in the disturbances were James Cathkin, Edward Cathkin, and Andro Hart. ${ }^{77}$ The Cathkins were brought before the King at Linlithgow, and committed to the Castle of Edinburgh, where, for a time, they were imprisoned. ${ }^{78}$

With his succession to the English throne in 1601, King James, delighted by the

72 Mason, 10, p. 252.

72 Burleigh, p. 202.

"Calderwood, pp. 165-6.

is It was Andrew Melville who upon a famous occasion plucked King James by the sleeve, called him 'God's sillie vassal' and reminded him that 'there are two Kings and two Kingdoms in Scotland. There is Christ Jesus the King and His Kingdom the Kirk, whose subject King James the Sixth is, and of whose Kingdom not a king, nor a lord, nor a head, but a member.'

10 Burleigh, p. 205.

77 According to Calderwood this had been brought about as a result of information laid against the Cathkins by Robert Stewart a Macer in Edinburgh. A London bookseller, John Norton had set up business in Edinburgh in 1587 and for a time had worked in association with Andro Hart in the importing and selling of books. In 1596 he gave up business and sold his books and debts to Edward Cathkin and Andro Hart. Among Norton's debtors was Robert Stewart who owed some $\mathbf{1 4 0 0}$ scots. To free himself of paying this debt Stewart notified the Cathkins to the authorities as being 'ringleaders of others to sedition, and emboldeners of the ministers in their present course.' (Calderwood, p. 364, and Bib. Soc. Dict; Norton, John.)

${ }_{78}$ Calderwood, p. 369. 


\section{W. B. Howie}

powers conferred upon him by the Anglican system of church government, became more determined than ever to establish similar forms in his native kingdom. Step by step he pushed towards his objective, re-establishing the power of the bishops, asserting his dominance, and finally in 1618 felt strong enough to alter the form of worship itself. At a General Assembly held at Perth Five Articles devised by the King for this purpose were introduced. These required (1) that communion be received kneeling, (2) that it might be administered to the sick privately, (3) that baptism might be administered in private if necessary, (4) that children should be confirmed by bishops at the age of eight years, and (5) that Christmas, Good Friday, Easter, Ascension and Whit Sunday be fittingly observed. Every possible pressure was exerted to secure the passage of the Articles, and members of the Assembly were threatened that the names of all who opposed them would be reported to the King. By a vote of 86 to 49 the Articles were finally accepted, but it was easier to secure the obedience of a limited group than of the country as a whole. ${ }^{79}$ By extremists the Five Articles were attacked as unscriptural and contrary to the will of God, and by moderates deplored for the dissension they introduced. The main controversy took place around the first and last articles. It was quite customary in the Kirk at this time to kneel for prayer, but never for communion. To the strict Calvinist kneeling implied adoration and was idolatrous. ${ }^{80}$

In such troublesome times James Cathkin inevitably reappears in the records of opposition. In February 1618 with Andro Hart and Richard Lawson he had been called before the Privy Council to explain by what authority they had printed an edition of the Catechism, this right having been granted to another printer Gilbert Dick. They were ordered to call in all the catechisms, to submit them for inspection and correction by the Archbishop of St. Andrews-Archbishop Spottiswoode-and then dismissed. ${ }^{81}$ A year later, in February 1619, with Richard Lawson and John Meyne, James Cathkin was once more summoned before the Court of High Commission, the three being accused of not going to Kirk on Christmas Day but opening their booths as if it were a normal day of trade, of attempting to dissuade others from going to Kirk, and of arguing against preaching on that day. They were treated with surprising leniency being 'dismissed with an admonition to be modest in their speeches and behaviour in time coming' ${ }^{82}$ In June, Cathkin found himself once more brought before the King, this time in London. Of this experience he has left his own account. He had travelled to London upon business, and upon arrival there found that an order had been issued for his arrest and examination. Next day he was taken by Bill, the King's Printer, with whom he had lodged, to Greenwich, where he was brought before James himself, supported by Spottiswoode and some of the Lords of the Council. The examination began on a simple note. 'First his Majestie demanded me “queher I duelt?' next “queher I was borne?" I said "If it pleas your Majestie I was borne in Edinburgh, and duells in Edinburgh".' But the interview soon became

79 Burleigh, p. 208.

${ }^{80}$ Snow, pp. 74-5. This view against kneeling for communion was not, however, universal, and there were those who approved of it. Dr. Michaelson, the Minister of Burntisland, compelled his congregation to kneel by the simple device of removing from the church all the stools upon which the congregation sat.

81 Mason, 11, p. 626. 


\section{Sir Archibald Stevenson}

serious. He was questioned as to his religion, and why he had not gone to church on Christmas Day. 'Because Sir, holie dayes have been castin out of our kirk, and hes ever bein preached against since ever I can remember.' This led to a prolonged theological argument and a good deal of choler on the part of the King. After this he was closely questioned about a book written by David Calderwood against the Perth Assembly. He denied having anything to do with the printing or selling of the book, but admitted he had seen a copy-in one of the Bishop's houses when visiting upon business, an innocence which did not improve the King's temper. He was asked if he had ever given shelter to David Calderwood-a wanted man-and after some prevarication admitted he had, but maintained it was innocently done. His examination completed, he was committed to prison, where he remained some days before being re-examined by Archbishop Spottiswoode at his own house in St. Martin's Lane. Here he was questioned as to the possibility of the book by Calderwood having been printed by Andro Hart, and whether or not he could identify the type. He was questioned as to its authorship and agreed it was probably written by Calderwood for it contained opinions he had heard him express in conversation. He was told that orders had been given for his house and booth in Edinburgh to be searched to see if any copies of the forbidden book were hidden there. Of the Five Acts the Archbishop said 'ye must either embrace them or leave the King's dominion' to which the old Calvinist made reply ' $I$ am content, for the Earth is the Lords, and it wer better to do that than to bring ane guiltiness upon my conscience that I could not be quit off.' At the end of this interrogation Cathkin was again returned to prison, but finally the Archbishop secured his release. Initially he was required to find surety for good behaviour both in England and Scotland, but since Bill (thinking perhaps of the safety of his office) declined to provide it, he was ultimately released without it and returned in safety to Edinburgh on $10 \mathrm{July} .^{83}$

This was not the end of James Cathkin's stormy career. In April 1620 he was again before the Privy Council in Edinburgh accused in company with Richard Lawson and William Rigge of encouraging 'the ministers who are refactorie to the ordor and constitutionis of the Kirk maid and concludit at the Assemblie of Perth in all thair disobedyence'. Having considered that in the past they had been treated with lenience in the hope of reclaiming them from their 'rebellious humour', the Council now resolved on sterner measures, and all three were ordered 'to addresse thame selffis to the country and boundis of Caithness within the speace of threttie dayis'. Failure to do so was to result in their being put to the horn (that is, outlawed) and having their goods forfeited. Cathkin and his friends appealed to the Town Council of Edinburgh for protection, and once again Spottiswoode saved them, stopping execution of the sentence, and finally persuading the King to remit it. ${ }^{84}$

James Cathkin was now over sixty years of age. The battle was not over, but

sannatyne, 1, pp. 199-214. James and his advisers were correct in thinking that the book they were concerned with had been written by David Calderwood, but they were wrong in presuming it had been printed in Scotland. It had in fact been printed in Holland and shipped over to Burntisland, where the copies had been smuggled ashore. The search of Cathkin's house carried out by the Edinburgh Magistrates and the Town Guard failed to find any incriminating evidenco-either Calderwood himself or copies of the book-though according to Calderwood five or six copies were hidden in the bedclothes of the bed in which he lay when being sheltered by Cathkin.

8 Mason, 12, pp. 249-51. 


\section{W. B. Howie}

perhaps he felt the time had come to leave it to younger men more able to stand the rigours of the fight, and his name disappears from the records of the Council. He lived for a further eleven years, dying on 30 September 1631 at the age of 72. After all debts had been paid his estate was divided equally between his widow Janet Mayne and his son-in-law the Rev. Andrew Stevenson. Each received $£ 2,368$ scots. ${ }^{85} \mathrm{He}$ had in stock some 4,400 books, of which perhaps significantly more than half were works of divinity. Janet Mayne carried on business as a bookseller until her death on 30 April 1639. Her Will was made up by Andrew Stevenson 'as father and lawful administrator to, and in name and behalf of Thomas, Archibald, James and Agnes Stevenson, minours, bairnes lawful to the said Mr. Andro Stevenson and oyes to the said defunct.' The sum left to the children was $£ 42614 s$. scots. ${ }^{86}$

This then was the inheritance of Sir Archibald Stevenson. Of these exploits of his grandfather he must often have heard from his stepmother, Edward Cathkin's daughter, and from his father who had his own testimony to add. To a man brought up in such a tradition Sir Robert Sibbald, with his easy passage from one belief to another (particularly when to the outside observer the vacillations could easily be associated with the pursuit of personal advancement) must have appeared the most despicable of time-servers. Religious beliefs were stronger then than now, and antagonisms founded upon such origins could be bitter, and the division deep. Upon Sir Robert's part perhaps the 'aristocratic' disapproval of the Rev. Colin Adam and his daughter embraced equally the Rev. Andrew Stevenson's son. Despite his personal success the landless Sir Archibald may at times have appeared to the proprietor of Kipps, and the descendant of Fife Lairds, to be of an inferior status, and any hint of such reaction would hardly improve relationships with a man of Sir Archibald's temperament.

Religious antagonisms may again have been at the root of the aversion between Stevenson and Burnet, but here political issues were also involved.

\section{THE POLITICS OF THE BURNET FAMILY}

With Sir Thomas Burnet we return, as in the case of Sibbald, to more aristocratic origins. He was born in 1638 the second son of Robert Burnet, Lord Crimond, one of the Judges of the Court of Session. His mother Rachael Johnston, of the Warriston family, was Lord Crimond's second wife. He graduated M.D. at Montpellier in 1659, and settled in Edinburgh as a physician. He was Physician to Charles II and James II, and then with equal ease accepted in 1693 appointment as Physician to William III, and later to Queen Anne. He was knighted in 1695 by William III, and this honour, together with his reappointment as Royal Physician was probably due to the influence of his younger brother Gilbert. ${ }^{87}$ Gilbert Burnet had entered the Scottish Church, and after having been minister of Saltoun in East Lothian for four years became Professor of Divinity at Glasgow in 1669. In 1673 on a visit to London he was appointed Chaplain in Ordinary to Charles II, and in the following year resigned his Chair in Glasgow and removed to London, where he was appointed preacher at the Rolls Chapel by the Master of the Rolls, and lecturer at St. Clement Danes. Originally of the Court Party he gradually moved into opposition and in 1683 attended

ss Bannatyne, 2, pp. 249-51. so Bannatyne, 2, pp. 253-4. 


\section{Sir Archibald Stevenson}

Lord Russell on the scaffold at his execution. In the following year he was prohibited from preaching in the Rolls Chapel and removed from his lectureship at St. Clement Danes. On the accession of James II he left England and travelled to Holland where he joined the Prince of Orange. On William III's landing in England Gilbert Burnet accompanied him as Chaplain, and in 1689 was duly rewarded for his services by being made Bishop of Salisbury. ${ }^{88}$ The Burnet family were, therefore, supporters of the revolution and the House of Orange. There is strong evidence that Sir Archibald Stevenson was a Jacobite. He gave his daughter Elizabeth in marriage to Pitcairn, a most ardent Jacobite, ${ }^{89}$ and upon his own retirement in 1705 secured by his influence the succession of Dr. George MacKenzie to his post of Physician to George Heriot's Hospital, a post from which MacKenzie was dismissed six years later because of his violent Jacobite opinions. ${ }^{\circ 0}$ Stevenson then was closely allied with those faithful to the House of Stewart, and since such associations were a bar to preferment (Pitcairn is said to have been forced to seek a Chair in Leyden because of his political beliefs) ${ }^{91}$ it is unlikely that he would willingly expose himself to such alliances unless holding similar beliefs.

Here then in the eternal problems of politics and religion may be found the basic source of the 'riot in the college'. Between Stevenson and Sibbald religious tensions; between Stevenson and Burnet political dispute. In the political field Pitcairn would be at one with his father-in-law in detesting all whigs. Perhaps, too, as has been suggested, social status played a part. Sibbald and Burnet were scions of the landed gentry and succeeded to estates; Stevenson's roots were more plebeian.

\section{THE HEALING OF THE BREACH, AND THE LAST DAYS OF SIR ARCHIBALD}

The schism produced by this dispute in the life of the Royal College remained unhealed for some time. At last however wisdom prevailed. On 31 January 1700 the first conciliatory moves were made. In an attempt to 'live in peace and unity' the acts of suspension pronounced against Stevenson, Pitcairn and all their party were taken off, provided they would appear and acknowledge the authority of the College before the first day of May following. This overture however Stevenson would not accept, and the Action between Stevenson and the College long carried on in the Court of Session was still pursued. In January 1703 another attempt was made to achieve unity, and the suspensions were taken off unconditionally, the suspended members being declared to have the right 'to sit vote and elect in the said College as any other Member thereof has.' At the election meeting in December 1703 Eccles, Olyphant and Smelholme, three of the Stevenson party, were present; Eccles was elected Censor, and Smelholme Treasurer. In January 1704 an Act of Oblivion to delete minutes referring to the quarrel was unanimously agreed, and in November 1704, on St. Andrews Day, the first reunited meeting of the College took place. Stevenson, Pitcairn and Sibbald were all again present, and as a final gesture of conciliation Sir Archibald was elected to the Council. 92

"Anderson, 1, pp. 489-93.

80 Their son Andrew Pitcairn was out in the '15, was captured, and would have been hanged but for the intercession of Mead, who wrote to Walpole on his behalf, and succeeded in gaining his release. The estate of Pitcairn was forfeited. (Pitcairn, pp. 373, 400.)

"Ritchie, p. 263.

92 Ritchie, pp. 179-81. 


\section{W. B. Howie}

Having returned to the College Sir Archibald continued to attend till 28 March 1706, his last recorded appearance. ${ }^{93} \mathrm{He}$ was then 77 years of age, and probably feeling the pressure of years. On 16 February 1710 he died in Edinburgh at the age of 81 , and two days later was buried in the Greyfriars Kirkyard, 94 where seventy-two years before the nobles, barons, ministers, burgesses and commons then in Edinburgh had signed their names to the National Covenant.

${ }^{93}$ Ritchie, p. 254.

${ }^{94}$ Ritchie, p. 203.

\section{BIBLIOGRAPHY}

A Relation of James Cathkin his Imprisonment and Examination about Printing of the Nullitie of Perth Assemblie, By Himself, Miscellany of the Bannatyne Club, vol. I, 1827.

Collection of the Wills of Printers and Booksellers in Edinburgh, Miscellany of the Bannatyne Club, vol. II, 1836.

A Dictionary of Printers and Booksellers in England, Scotland and Ireland 1557-1640, London, Bibliographical Society, 1910.

History of the Society of Writers to His Majesty's Signet, Edinburgh, T. and A. Constable, 1936.

Scots Magazine.

ANDERson, William, The Scottish Nation, Edinburgh, Fullarton, 1869.

Burleigh, J. H. S., A Church History of Scotland, London, Oxford University Press, 1960.

CALDERwOOD, DAVID, The True History of the Church of Scotland, Published by order of the General Assembly, Edinburgh, 1704.

Clark, Sir Grorge, A History of the Royal College of Physicians of London, Oxford, Clarendon Press, 1964.

CoMrIE, JoHn D., History of Scottish Medicine to 1860, London, Baillière, Tindal \& Cox, 1927.

Grant, JAMES, History of Burgh and Parish Schools of Scotland, London and Edinburgh, William Collins, 1876.

GuthriE, Douglas, 'The influence of the Leyden School upon Scottish Medicine', Med. Hist., 1959, 3, 108-22.

Hett, Francis Paget (ed.), Memoirs of Sir Robert Sibbald 1641-1722, London, Humphrey Milford, 1932.

Mason, David (ed.), Register of the Privy Council of Scotland, First Series, vols. X, XI, XII, 1891-1895.

Paton, HenRy (ed.), Register of Marriages of the City of Edinburgh 1595-1700, Scottish Record Society, 1905.

Pitcairn, Constance, The History of the Fife Pitcairns, London and Edinburgh, William Blackwood, 1905.

RAIT, ROBERT S., The Making of Scotland, London, A. \& C. Black, 1929.

RITCHIE, RoBert PEel, The Early Days of the Royal Colledge of Phisitians, Edinburgh, George P. Johnston, 1899.

ScotT, Hew, Fasti Ecclesiae Scoticanae, Edinburgh, Oliver \& Boyd, 1925.

Smout, T. C., Scottish Trade on the Eve of the Union 1660-1707, Edinburgh, Oliver \& Boyd, 1963.

Snow, W. G. Sinclair, The Times, Life and Thought of Patrick Forbes, Bishop of Aberdeen 1618-1635, London, S.P.C.K., 1952.

Watson, Charles B. Boog (ed.), Roll of Edinburgh Burgesses 1406-1700, Scottish Record Society, 1926-9.

Wood, WalTER, The East Neuk of Fife, Edinburgh, David Douglas, 1887. 